\title{
A desalination guide for South African municipal engineers
}

\author{
CD Swartz ${ }^{1 *}$, JA du Plessis ${ }^{2}$, AJ Burger ${ }^{3}$ and G Offringa ${ }^{4}$ \\ ${ }^{1}$ Chris Swartz Water Utilisation Engineers, PO Box 745, Mossel Bay 6500, South Africa \\ ${ }^{2}$ Department of Civil Engineering, Stellenbosch University, Private Bag X1, Matieland 7602, South Africa \\ ${ }^{3}$ Department of Process Engineering, Stellenbosch University, Private Bag X1, Matieland 7602, South Africa \\ ${ }^{4}$ Water Research Commission, Private Bag X03, Gezina, Pretoria, 0031, South Africa
}

\begin{abstract}
Municipalities need to develop Water Services Development Plans (WSDPs) as a first requirement in their budgetary process, and need to be made aware of the options that are available to provide more than basic services. While $25 \ell /$ person $\cdot d$ has been set as the minimum basic water supply and while many consumers receive far in excess of this amount, there are areas of the country where water of acceptable quality is not available for household use. However, in many areas adequate quantities of saline water may be, or are, readily available. This is especially the case for coastal cities and towns.

The cost of treating water is only part of the total cost of making drinking water available to the consumer. This together with the fact that membrane technology is becoming more affordable and that energy can be recovered, makes the desalination of water viable for domestic purposes.

A desk study, funded by the Department Water Affairs and Forestry and managed by the Water Research Commission, was undertaken to identify treatment options for desalinating seawater from both the Indian and Atlantic oceans or brackish water from boreholes. The specific objectives of the project were to compile a Guide on the technologies that can be implemented in South Africa to treat saline water to drinking water standards, to identify the pretreatment that is necessary, and to present guidelines on operational, maintenance, management and environmental aspects relevant to the selection and use of these technologies. An important aspect was also to quantify the capital and operating costs for planning purposes of the different components needed to successfully bring the water to the accepted standards for potable and domestic use.

Of particular importance for the South African application was to identify the level of skills required for daily operation of the desalination plants, the level of skills required to provide technical back-up and advice, and to identify and advise on the competencies, training needs and capacity building required at operator and management levels. Lastly, the relevant local environmental legislations governing desalination were also identified.
\end{abstract}

Keywords: desalination, municipal water treatment, reverse osmosis, pretreatment, post-treatment, operation and maintenance, environmental aspects, residuals management

\section{Desalination technologies appropriate for South African conditions}

Thermal distillation systems account for the majority of the world's seawater desalination capacity, while membrane-based reverse osmosis systems (newer technology than distillation) are rapidly gaining ground. Distillation systems are more energy intensive (up to four times more) than reverse osmosis systems, but require less pretreatment of the water and are therefore generally considered to be more robust. However, most distillation plants are located in the Middle East where low-cost energy is available and where these plants run in combination with electrical power stations (using low-pressure steam, discharged from the turbines, as energy source).

In the South African context, thermal desalination processes would normally not be considered for desalination of brackish or seawater, unless sufficient waste heat or low cost fuels are available (e.g. in combination with nuclear power generation). Until recently, the upper capacity limit for reverse osmosis (RO) desalination of seawater was considered to be around 100000 $\mathrm{m}^{3} / \mathrm{d}$, while plants with larger capacities were always based on distillation. However, the Ashkelon desalination plant in Israel,

This paper was originally presented at the 2006 Water Institute of South Africa (WISA) Biennial Conference, Durban, South Africa, 21-25 May 2006.

* To whom all correspondence should be addressed.

표+2744 691-1242; fax:+2744 690-7960; e-mail: sswartz@mweb.co.za one of the most recent additions to large-scale seawater desalination plants, has a production capacity of $330000 \mathrm{~m}^{3} / \mathrm{d}$ and is, despite its 'large' capacity, a RO plant. Therefore, considering the relatively low cost of electricity in South Africa and the typical capacity requirements of potential South African desalination plants, reverse osmosis (RO) would almost always be the process of choice. This statement is supported by the following facts:

- A detailed costing study by Namwater (Namibia) for a desalination plant at Swakopmund indicated that RO would be less expensive than thermal distillation

- After an in-depth assessment, Perth (Australia) is progressing with the design of a seawater RO plant

- Sydney (Australia) is considering RO as their method of choice for desalination

- The new, large (330 M $\ell / \mathrm{d})$ desalination plant in Ashkelon (Israel) utilises RO

- Several other RO plants with capacities of around or above $100 \mathrm{M} \ell / \mathrm{d}$ have recently been constructed in the UAE, Singapore and elsewhere

- Existing seawater and brackish water desalination plants in South Africa and Botswana that provide water for municipal use are all RO plants.

Further, because of its substantially lower energy use, RO will have a much lower life-cycle cost than thermal desalination and contribute much less in terms of greenhouse gases than thermal distillation. Therefore, apart from describing the fundamental 
principles of operation for evaporation/distillation plants, no effort will be made to provide relevant step-wise costing rules. Distillation experts should be contacted in (rare) cases where the municipal engineer is of the opinion that thermal desalination could be applicable.

For small capacity plants (a few $\mathrm{m}^{3} / \mathrm{h}$ or less) alternative technologies (such as solar desalination) may in some cases be considered, but the reader is specifically referred to Goldie and Sanderson (2004) in this regard.

\section{Guidelines and procedures for process selection and costing}

The guidelines on desalination and cost estimation are provided with the understanding that such information shall be utilised within context and with due consideration and understanding of the following important aspects:

- Saline water source, energy source and process selection Compared to conventional municipal water treatment, desalination processes are energy intensive. No assessment of a desalination process is complete without proper understanding of the energy requirements and the available sources and cost of energy (e.g. residual steam, spent heat, electricity, etc.). The source of energy, the required plant capacity and the feed water quality play major roles in the selection of the most appropriate desalination process.

\section{- Fouling, scale formation and plant availability}

Water $\left(\mathrm{H}_{2} \mathrm{O}\right.$ in its pure form) contains dissolved gases, dissolved and suspended inorganic solids, dissolved and suspended organic matter and suspended micro-organisms. During the desalination process, the concentration of these components can effect various forms of scale formation and other inhibitive contamination of the desalination equipment. As such, continuous scaling and/or fouling can be one of the most crippling side-effects of desalination processes. A well-designed desalination plant always incorporates a well-designed and appropriate pretreatment system to minimise fouling. As such, a thorough knowledge of the feed water chemistry and related seasonal variations is essential.

- Disposal of concentrate and environmental considerations At first consideration, one often tends to ignore the fact that the concentrate (which can be several times more saline than the feed - depending on the application) needs to be disposed of in an appropriate and environmentally friendly manner. However, quite often this unavoidable consequence of the desalination process can contribute to a major portion of the overall project cost

\section{- Physical location of plant and cost of distribution}

Augmentation of municipal water by desalination requires a sensible tie-in into established municipal water supply networks. The selection of an optimum location for a desalination plant in relation to its feed source and its tie-in point can sometimes be less clear-cut than expected. Incorrect positioning can contribute to significant additional capital and operating costs.

\section{- Manufacturing specifications and plant life}

Incorrect selection of materials of construction and inferior equipment can have serious adverse effects on both the maintenance costs and general operability and availability of the plant. Therefore, clear and unambiguous definitions of the minimum required plant life and construction specifications are essential to avoid plant failure and consequent overhaul after a few years of operation.

The rules and procedures are based on experience and information from the literature. The main steps and guidelines are summarised in Fig. 1.

\section{South African saline water sources}

\section{Seawater}

South Africa with its extremely long coastline has an almost infinite water resource available to the coastal towns and cities of the country, albeit of a highly saline nature. Three seawater zones with potentially different water qualities are identified and briefly discussed below.

\section{- East Coast}

The East Coast of South Africa can be described as the area between East London up to the Mozambique border. All marine systems in this region are dominated by the Agulhas current, which brings warm, nutrient-poor water from the tropics to the east coast. The region can be subdivided into a tropical coast (north of Port Edwards) and a subtropical coast.

\section{- South Coast}

The coastal region between East London and Cape Agulhas, referred to as the South Coast, acts as a transitional zone between the warm east-coast waters and the cold west-coast waters, with no clear boundaries. Boundary conditions might shift $100 \mathrm{~km}$ in either way, depending on prevailing atmospheric conditions.

\section{- West Coast}

The West Coast is generally referred to as the region between Cape Agulhas and the mouth of the Orange River. Seawater quality in this region can be rather variable and special care should be taken when assessing water supply in areas such as False Bay, St Helena Bay and the Saldanha Bay / Langebaan system. Due to the north-bound flow of the Benguela Current from the Antarctic, the west-coast water is normally very cold and associated with low dissolved oxygen levels. Prevailing wind conditions frequently result in an up-welling of cold, nutrient-rich bottom water into the warmer surface water, triggering the associated red-tide phenomenon and the potential presence of $\mathrm{H}_{2} \mathrm{~S}$ in the water. The low water temperature demands higher operating pressures and lower membrane fluxes, while the high concentrations of nutrients and potential compounds such as $\mathrm{H}_{2} \mathrm{~S}$ cause the pretreatment to be demanding. Therefore, desalination of west-coast water would normally be more expensive than on the East Coast.

\section{Groundwater}

Saline or brackish groundwater provides for a second alternative source of water. The specific desalination technology required will, as in the case of seawater, depend on the quality of the available groundwater. The groundwater exploitation potential maps, together with the groundwater quality, provide a good estimate of the probability that groundwater of a specific quality (TDS in 


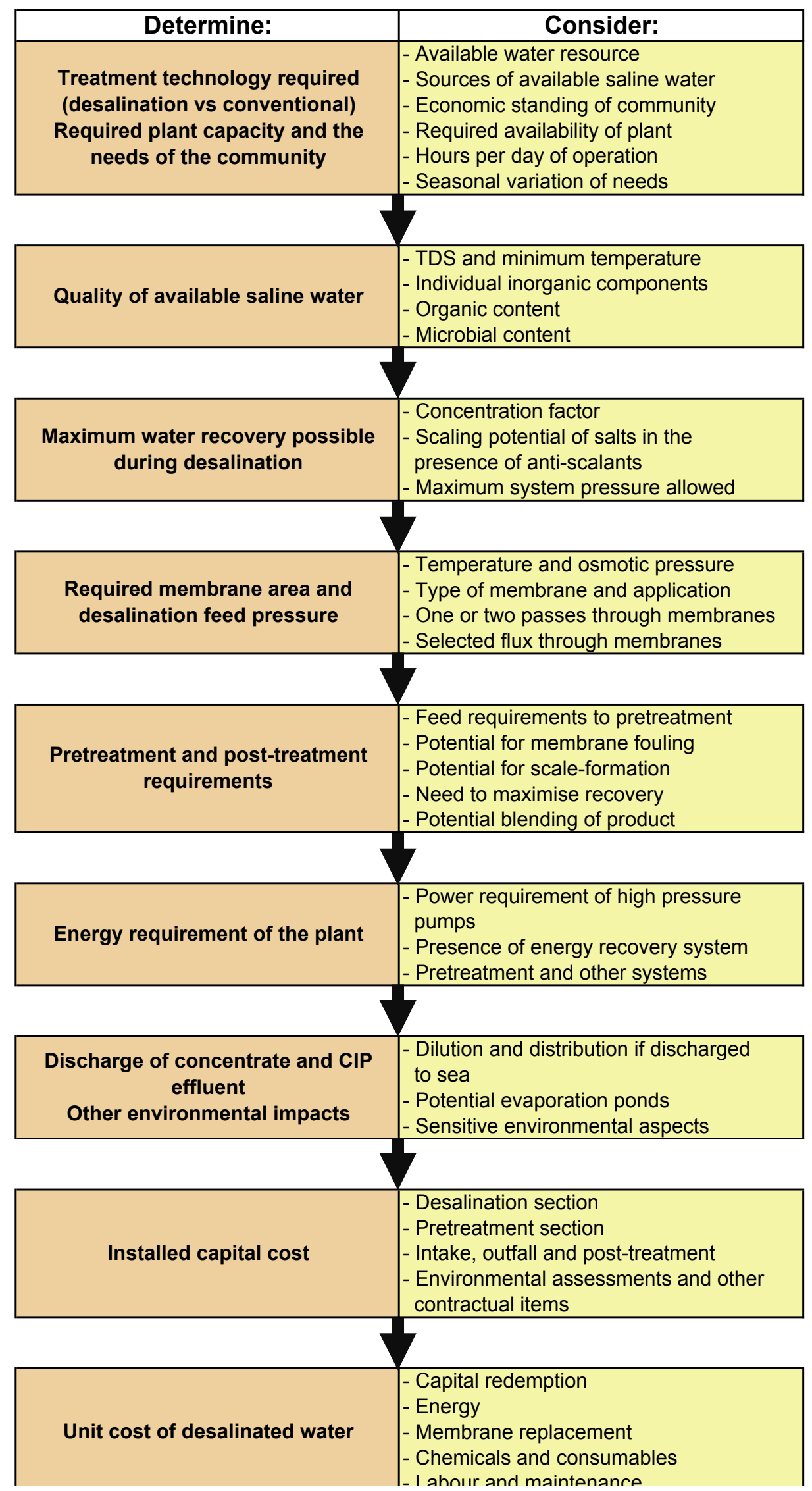

Figure 1

Process selection and costing 


\begin{tabular}{|c|c|c|c|c|c|c|c|}
\hline \multicolumn{8}{|c|}{$\begin{array}{c}\text { TABLE } 1 \\
\text { Cost estimates for brackish water RO desalination plants }\end{array}$} \\
\hline Plant and raw water type & \begin{tabular}{l}
$\overrightarrow{7}$ \\
\multirow{0}{0}{} \\
$\mathbb{0}$ \\
$\frac{0}{\pi}$ \\
0 \\
0
\end{tabular} & 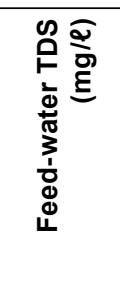 & 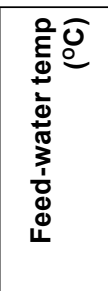 & 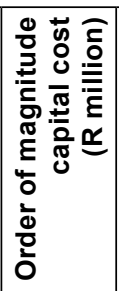 & 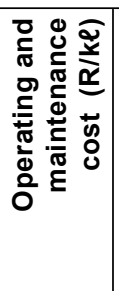 & 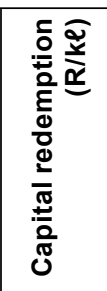 & 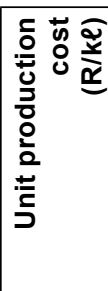 \\
\hline Low TDS standard pretreatment & \multirow{4}{*}{$\begin{array}{l}\stackrel{\Xi}{\Xi} \\
\stackrel{\Xi}{\Xi} \\
\simeq\end{array}$} & 2000 & 17 & 1.43 & 2.80 & 2.50 & 5.30 \\
\hline Low TDS full lime pretreatment & & 2000 & 17 & 2.07 & 4.90 & 3.60 & 8.50 \\
\hline High TDS standard pretreatment & & 12000 & 17 & 1.43 & 3.10 & 2.50 & 5.60 \\
\hline High TDS full lime pretreatment & & 12000 & 17 & 2.27 & 5.50 & 3.90 & 9.40 \\
\hline Low TDS standard pretreatment & \multirow{4}{*}{ 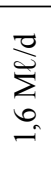 } & 2000 & 17 & 6.22 & 1.60 & 1.40 & 2.90 \\
\hline Low TDS full lime pretreatment & & 2000 & 17 & 9.18 & 3.30 & 2.00 & 5.30 \\
\hline High TDS standard pretreatment & & 12000 & 17 & 6.22 & 1.90 & 1.40 & 3.30 \\
\hline High TDS full lime pretreatment & & 12000 & 17 & 9.85 & 3.70 & 2.20 & 5.90 \\
\hline Low TDS standard pretreatment & \multirow{4}{*}{$\begin{array}{l}\frac{D}{j} \\
\sum_{0} \\
0 \\
n\end{array}$} & 2000 & 17 & 16.1 & 1.30 & 1.10 & 2.40 \\
\hline Low TDS full lime pretreatment & & 2000 & 17 & 23.4 & 2.80 & 1.60 & 4.40 \\
\hline High TDS standard pretreatment & & 12000 & 17 & 16.1 & 1.60 & 1.10 & 2.70 \\
\hline High TDS full lime pretreatment & & 12000 & 17 & 24.5 & 3.20 & 1.70 & 4.90 \\
\hline
\end{tabular}

\begin{tabular}{|c|c|c|c|c|c|c|c|}
\hline \multicolumn{8}{|c|}{$\begin{array}{r}\text { TABLE } 2 \\
\text { Cost estimates for seawater } R\end{array}$} \\
\hline $\begin{array}{l}\text { Plant and raw } \\
\text { water type }\end{array}$ & 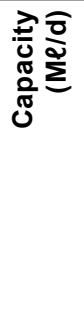 & 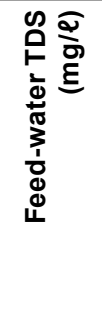 & 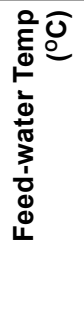 & 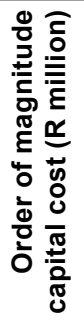 & 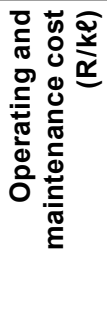 & 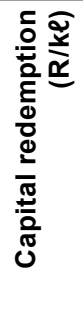 & 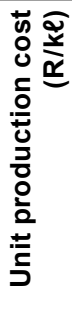 \\
\hline \multirow{2}{*}{ West Coast } & 5 & 36000 & 9 & 63 & 4.00 & 4.40 & 8.40 \\
\hline & 50 & 36000 & 9 & 530 & 3.30 & 3.70 & 7. 00 \\
\hline \multirow{2}{*}{ South Coast } & 5 & 36000 & 16 & 46 & 3.30 & 3.20 & 6.50 \\
\hline & 50 & 36000 & 16 & 394 & 2.80 & 2.80 & 5.60 \\
\hline \multirow{2}{*}{ East Coast } & 5 & 36000 & 21 & 40 & 3.00 & 2.80 & 5.80 \\
\hline & 50 & 36000 & 21 & 338 & 2.60 & 2.40 & 5.00 \\
\hline
\end{tabular}

$\mathrm{mg} / \ell$ ) can be found in an area and whether the resource can be considered as a potential alternative water resource. However, the presence of specific compounds, such as iron, manganese, fluorides and nitrates, will require special attention.

\section{Comparative cost estimates for desalination in South africa}

Table 1 and Table 2 summarise cost estimates that were developed by applying the rules provided in the Guide (Du Plessis et al, 2006), while considering the typical characteristics and quality of saline water predominantly found in certain areas of South Africa. No attempt was made to provide cost estimates for all potential options and innovations (be it low-cost or expensive).

More detailed costs and description of conditions and assumptions as applied in these rules are provided in the Guide. Important notes on inclusions and exclusions are provided at the end of these tables.

Notes applicable to Table 1 and Table 2:

- For 'low' TDS (ca $2000 \mathrm{mg} / \ell$ ) brackish water desalination, a recovery of $60 \%$ (conservative) is used for standard pretreatment, and $85 \%$ recovery when using lime pretreatment

- For 'high' TDS (ca $12000 \mathrm{mg} / \ell$ ) brackish water desalination, a recovery of $60 \%$ (conservative) is used for standard pretreatment, and $75 \%$ recovery when using lime pretreatment

- Plant life is assumed to be 25 years. Therefore, capital redemption is estimated for 25 years at an annual interest rate of $12 \%$.

- Capital cost estimates are complete installed costs, including all process, civil, mechanical, electrical and control works, but excluding the following:

- Large product storage reservoirs and subsequent municipal distribution systems. These are considered to be part of any water treatment system and cannot be directly attributed to the cost of a desalination plant.

- Access roads outside the equipment area, as well as laboratories and administration offices.

- Electricity generation or installation of power supply lines over long distances. 


\begin{tabular}{|c|c|c|c|}
\hline \multicolumn{4}{|c|}{$\begin{array}{l}\text { TABLE } 3 \\
\text { Typical water production costs for desalination plants and conventional water treatment plants }\end{array}$} \\
\hline \multicolumn{2}{|r|}{ Treatment System } & \multirow{2}{*}{\begin{tabular}{|c|}
$\begin{array}{c}\text { Water } \\
\text { production } \\
\text { cost } \\
\text { (R/ke) }\end{array}$ \\
3.39 \\
\end{tabular}} & \multirow{2}{*}{$\begin{array}{l}\text { Notes } \\
\text { w water }\end{array}$} \\
\hline \multirow{5}{*}{ 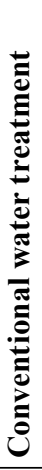 } & $\begin{array}{l}\text { Amatola Water } \\
\text { (For } 14 \text { water treatment plants) }\end{array}$ & & \\
\hline & $\begin{array}{l}\text { Rand Water } \\
\text { (For } 6 \text { large water treatment plants, treating a } \\
\text { total of } 5260 \mathrm{M \ell} / \mathrm{d})\end{array}$ & 2.53 & $\begin{array}{l}\text { Conventional water treatment plants. Cost includes purchase of } \\
\text { raw water. }\end{array}$ \\
\hline & 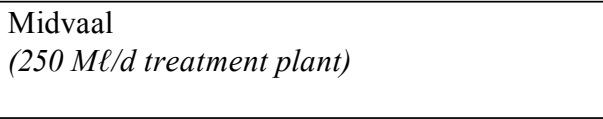 & 2.52 & $\begin{array}{l}\text { Treatment plant includes ozonation and dissolved air flotation } \\
\text { for treating eutrophied water. Cost includes } \\
\mathrm{R} 1.52 / \mathrm{k} \ell \text { for purchase of raw water. }\end{array}$ \\
\hline & $\begin{array}{l}\text { City of Cape Town } \\
\text { (various plants) }\end{array}$ & $1.05-1.25$ & $\begin{array}{l}\text { Includes raw water costs (which include the new Berg River } \\
\text { Water project and excludes bulk management and conveyance) }\end{array}$ \\
\hline & $\begin{array}{l}\text { Withoogte } \\
\text { (72 MQ/d treatment plant) }\end{array}$ & 1.04 & $\begin{array}{l}\text { Conventional water treatment plant. Cost includes purchase of } \\
\text { raw water. Only small portion of capital redemption remains. }\end{array}$ \\
\hline \multirow{5}{*}{ 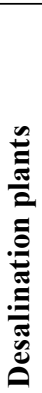 } & $\begin{array}{l}\text { Bitterfontein } \\
\left(12 \mathrm{~m}^{3} / \mathrm{h} \text { RO groundwater desalination plant }\right)\end{array}$ & 7.81 & $\begin{array}{l}\text { Relatively high cost for management functions and transport } \\
\text { due to remote location of the RO plant }\end{array}$ \\
\hline & $\begin{array}{l}\text { Boesmansriviermond } \\
\left(45 \mathrm{~m}^{3} / \mathrm{h} \text { RO seawater desalination plant }\right)\end{array}$ & 2.26 & $\begin{array}{l}\text { Cost includes electricity, labour, membrane replacement (every } \\
5 \text { years) and pump maintenance, but excludes capital redemption }\end{array}$ \\
\hline & $\begin{array}{l}\text { Costing model } \\
\left(15 \mathrm{~m}^{3} / \mathrm{h} \text { RO groundwater desalination plant }\right)\end{array}$ & $5.30-9.40$ & $\begin{array}{l}\text { Range is for low TDS }(2000 \mathrm{mg} / \ell)(\text { lower cost) and high TDS } \\
(12000 \mathrm{mg} / \ell)(\text { higher cost) }\end{array}$ \\
\hline & $\begin{array}{l}\text { Costing model } \\
(5 \mathrm{M \ell} / \mathrm{h} \text { RO groundwater desalination plant })\end{array}$ & $2.40-4.90$ & $\begin{array}{l}\text { Range is for low TDS }(2000 \mathrm{mg} / \ell)(\text { lower cost) and high TDS } \\
(12000 \mathrm{mg} / \ell)(\text { higher cost) }\end{array}$ \\
\hline & $\begin{array}{l}\text { Costing model } \\
(5 \mathrm{M} / \mathrm{d} \text { RO seawater desalination plant })\end{array}$ & $5.80-8.30$ & $\begin{array}{l}\text { Range is for East Coast water (lowest cost), South Coast water } \\
\text { and West Coast water (highest cost) }\end{array}$ \\
\hline
\end{tabular}

- Potential expropriation of land and/or existing infrastructure.

- Full-blown lined evaporation ponds for brackish water RO systems (note that such ponds may effect a drastic increase in the total capital cost).

- Potential development of boreholes.

- Note that operation and maintenance costs can vary drastically from site to site. For example, small plants at remote locations (relatively far removed from their managerial centres or municipalities) may have operating costs much higher than the 'typical' values stated above).

\section{Comparison of desalination plant operational costs and cost stucture with conventional treat- ment plants}

The operational cost breakdown of an existing desalination plant in South Africa, and cost figures obtained from the costing guidelines, were compared with operational costs of a number of conventional treatment plants in the country. The results are presented in Table 3. The costs used in the comparisons vary significantly due to the different methods used by the authorities to reflect all the different cost aspects in the production cost. It was not always possible to ring fence the same criteria for all the treatment plants used.

\section{Pretreatment methods}

Pretreatment to desalination processes forms an important and integral part of desalination installations, and is often a major cost consideration in the selection of desalination as a water treatment alternative. This holds true especially for seawater desalination, and in particular for West-Coast seawater in South Africa.

A variety of pretreatment methods may have to be employed to ensure that optimal desalination plant performance is achieved. These processes may be needed for one or more of the following: particulate and fine material removal; suspended solids removal; organics removal; biofouling prevention; control of biological activity (disinfection as well as dechlorination if chlorine is used); prevention of scaling and inorganic precipitation, including metals removal and removal of other elements such as sulphur and silica.

Pretreatment processes may be relatively simple in the case of good quality groundwater, sometimes requiring only cartridge filtration and possible dosing of anti-scalants. For poor quality feed water, extensive chemical treatment (such as lime softening) may be required to maximise recovery, although most engineers would attempt to avoid such complication in the design. For seawater, pretreatment normally requires extensive pre-filtration, which may consist of two-stage sand filtration (media filtration) with pre-flocculation or even media filtration in combination with ultra-filtration.

For prevention of biofouling or control of biological activity, or for oxidation of metals such as iron, an oxidation step may be needed. Chlorination and ozonation are among oxidation processes that can be employed.

\section{Post-treatment of desalinated water}

Post-treatment of desalinated water has two objectives, viz. stabilisation and final disinfection. Like most conventional water treatment plants, disinfection entails the dosing of a disinfectant (usually chlorine) to prevent biological growth in subsequent municipal reservoirs and distribution systems. Since organic 
matter and microbial organisms are removed by the desalination process, chlorine requirements are relatively low.

Depending on the plant design, the desalinated product water may have a TDS well below $30 \mathrm{mg} / \ell$, containing negligible concentrations of calcium, magnesium and carbonate. Such water is corrosive and needs to be stabilised before final distribution. Loewenthal et al. (1986) compiled an excellent monograph to explain the principles of stabilisation, indicating that a positive $\mathrm{CaCO}_{3}$ precipitation potential (preferably above 3) is required. The principles have been incorporated into a software package on CD, Stasoft4 (WRC, 2000) which simplified the calculations considerably. Suffice to say that stabilised water, fit for municipal and potable use, typically has a $\mathrm{pH}$ of between 8 and 8.5 , contains approximately $20 \mathrm{mg} / \ell \mathrm{Ca}$ and has an alkalinity of above $50 \mathrm{mg} / \ell$.

Single-pass seawater RO plants typically produce permeates with TDS in the order of $300 \mathrm{mg} / \ell$ which, if blended in with larger volumes of other municipal water, may only require minimal post-treatment such as $\mathrm{pH}$ adjustment by lime addition. However, a fully desalinated product that is used as single source of municipal water supply needs better post treatment, entailing $\mathrm{pH}$ adjustment with $\mathrm{CO}_{2}$ and dissolution of lime, or limestone (usually via limestone filters). In some cases (only smaller plants) calcium chloride, sodium bicarbonate and sodium carbonate are dosed to produce the required levels of $\mathrm{CaCO}_{3}$ in the water.

\section{Management of residuals (brine disposal)}

During the desalination process, it is inevitable that waste streams are generated, which must be managed in a suitable way. The treatment and disposal of these residuals, within the legal environmental framework, may result in significant costs for the water service provider.

The most important and largest waste stream from any desalination plant is the brine (or concentrated salt) stream that is produced during the separation process. The brine stream contains high concentrations of salts and other concentrated impurities that may be found in the feed water, and which must be disposed of in a safe and acceptable way. Depending on the composition of the brine and the location of the site, additional treatment may be required before disposal.

The character of the brine that is produced will be affected by feed water quality, pretreatment processes, desalination processes, water recovery and post-treatment and concentrate blending.

The most common brine disposal options are ocean disposal, surface water discharge, sewer discharge, deep-well injection (not applied in South Africa at present), evaporation ponds, land application and co-disposal with wastewater treatment plant effluent or power plant cooling water.

\section{Environmental considerations}

When considering desalination as an alternative option to conventional water supply, it is important to carefully take into account all the environmental costs associated with the development and operation of desalination plants. The following legislation and permit requirements are applicable:

\section{- The National Environmental Management Act (Act} 107/98, NEMA)

NEMA promotes sustainable development and regulates the procedures and steps to be taken when a development is considered for approval. It specifically promotes the cooperation between different role players and cooperative governance.

In this regard, it prescribes cooperation between government departments, such as the Department of Water Affairs and Forestry (DWAF), the Department of Environmental Affairs and Tourism and the relevant local authority. In specific instances, institutions such as Nature Conservation Boards will also need to be consulted.

\section{- Environmental Conservation Act (Act 73/89, ECA)}

ECA, through regulation 1182, prescribes specific requirements for specific actions that might have a detrimental impact on the environment. These actions are listed in schedule one of the regulations and include "construction or upgrade of all structures below the high-water mark of the sea' and 'schemes for the abstraction or utilisation of ground or surface water for bulk supply purposes'.

Regulation 1182 contains all the relevant steps to be taken for the required environmental impact assessment. It is extremely important to note that the involvement of interested and affected parties forms an integral part of this process.

\section{- National Water Act (Act 36 of 1998, NWA) and} Water Services Act (Act 108 of 1997, WSA).

These two acts regulate the water industry and deal primarily with the management structures and the licensing procedures required before water can be abstracted from a source.

In the case of the abstraction of groundwater, the permit or licensing procedure is well described and is compulsory through the WSA.

The concentrated wastewater generated from a desalination plant contains high concentrations of salt and particulate matter, which have the potential to impact negatively on the receiving environment. In the case of reverse osmosis plants, filter backwash water (or sludge) and CIP chemicals need to be disposed of, apart from the concentrated brine. Thermal desalination plants, driven by auxiliary boilers, also discharge fumes $\left(\mathrm{CO}_{2}\right.$, $\mathrm{NO}_{\mathrm{x}}$, and $\mathrm{SO}_{\mathrm{x}}$ ) and cooling water blow-down with associated heat into the environment.

\section{Skills required for operation and maintenance of desalination plants}

\section{Operating}

The operation of a desalination plant can be performed under contract, but it is preferable that the plant is operated by personnel of the water service provider (municipality or water board). Operating a desalination plant is not necessarily more difficult than operating a conventional water treatment plant, but a lack of adequate control measures during the operational phase can be very costly in terms of membrane life expectancy and therefore operational cost. The maintenance cost for desalination is normally also slightly higher than that of conventional treatment plants due to the higher pressure pumps and membrane cleaning processes required.

Perhaps the most important aspect of the operation of any desalination plant is the availability of accurate data on which decisions regarding the operational aspects can be based. If a specific plant is operated by an external company, then the water service authority must have adequate access to all the relevant data. 
The day-to-day operations of desalination plants do not require any special formally qualified staff. However, plant operators should be well-trained and capable of acquiring the skills necessary to perform daily operations of the plant and to report any deviations from normal operating parameters. Chemical cleaning of membranes needs to be performed under the control and guidance of a knowledgeable supervisor or technician.

It is advisable that at least one staff member of the water service provider has an adequate understanding and knowledge of membrane treatment processes. This would require some form of training in membrane treatment, albeit short courses or as part of formal training. This staff member would either be a technician, technologist or an engineer (depending on the size of the plant).

\section{Maintenance}

Sufficient funds and labour must be available to do preventative maintenance. A good preventative maintenance program will document the schedule and work plan for each maintenance function. This schedule serves as the basis for estimation of labour requirements for specific maintenance functions. To determine trade and man-hour requirements for each preventative maintenance function, the function should be broken down into tasks. Such tasks may then be analysed further to determine specific skills and man-hours required for each specific maintenance function.

It is important to use trained and experienced individuals to perform maintenance. At larger service providers, individuals who are specialised in each trade will in all likelihood be available to do the required maintenance. If not, it is advisable to contract specialised maintenance work, such as electrical control panel repair or generator maintenance out to private contractors. Full dependence on contractors for maintenance tasks needs to be minimised where possible. However, due to cost implications it might be the most appropriate option, specifically for smaller communities.

\section{Technical support}

Technical support for desalination plants is necessary to ensure that any deviations from normal operating regimes are addressed rapidly and effectively, so that service delivery (volume of water produced and quality of product water) is not compromised. The support would normally comprise rapid response to call-outs, trouble shooting and corrective action to normalise the situation. It would also include action plans to rapidly identify/forecast similar problems in future and communicating this to the municipal engineer.

Technical support can be provided by any of the following:

- Membrane plant supplier

- Contracted external company

- Competent municipal technician.

The latter would again be the option of choice, but additional support by the membrane supplier would be strongly recommended.

\section{Qualifications}

The following qualifications are recommended:

\section{Operating personnel}

- Plant Operators

Grade 12 and in-service training on the desalination plant (NQF 4 equivalent)

- Supervisor

Qualification in water treatment and short course on membrane treatment (B.Tech. equivalent).

\section{Maintenance personnel}

In-service training by membrane suppliers during commissioning process.

\section{Technical support personnel}

Qualification in water treatment and short course on membrane treatment. In-service training by membrane suppliers during commissioning process.

\section{Training requirements}

Existing plant operators (process controllers) at municipal treatment plants can be trained to operate desalination plants. The operators should at least have a Grade 12 school qualification and should receive in-service training on the operation of desalination plants during the commissioning of such plants.

\section{Conclusion}

RO membrane treatment presents a viable option for drinking water supply from alternative water sources in South Africa (desalination of seawater and brackish water) to supplement the dwindling existing water resources. Both capital and operating costs of RO plants have decreased significantly during the past two decades, making it an increasingly attractive option for coastal towns to supplement their drinking water supply.

\section{Acknowledgements}

Funding of the project by the Department Water Affairs and Forestry (managed by the Water Research Commission), and permission to present this paper, is gratefully acknowledged by the authors.

\section{References}

DU PLESSIS JA, BURGER AJ, SWARTZ CD and MUSEE N (2006) A Desalination Guide for South African Municipal Engineers. WRC Report No. TT 266/06, Water Research Commission, Pretoria, South Africa.

GOLDIE I and SANDERSON RD (2004) A Guidebook on Household Water Supply for Rural Areas with Saline Groundwater. WRC Report No. TT 221/04, Water Research Commission, Pretoria, South Africa.

LOEWENTHAL RE, WIECHERS HNS and MARAIS GvR (1986) Softening and Stabilization of Municipal Waters. WRC Report No. TT 24/86, Water Research Commission, Pretoria,South Africa.

MORRISON IR and LOEWENTHAL RE (2000) Stasoft4 for Windows 95, 98 and NT. Water Research Commission, Pretoria, South Africa. 